\title{
PENGARUH DOSIS DAN UKURAN BUTIR PUPUK FOSFAT SUPER YANG DIASIDULASI LIMBAH CAIR TAHU TERHADAP SERAPAN P DAN PERTUMBUHAN TANAMAN JAGUNG (Zea mays L.)
}

\author{
Debby Novita Sari, Sri Yusnaini, Ainin Niswati \& Sarno \\ Jurusan Agroteknologi Fakultas Pertanian Universitas Lampung \\ Jl. Prof. Dr. Soemantri Brodjonegoro No. 1 Bandar Lampung 35141 \\ Email: Deby.db62@gmail.com
}

\begin{abstract}
ABSTRAK
Sumber P yang saat ini digunakan dalam pertanian umumnya adalah pupuk kimia seperti SP-36 dan TSP, dengan ditiadakannya subsidi pupuk $\mathrm{P}$ ini maka harga pupuk meningkat di pasaran karena semua bahan baku pembuatan pupuk tersebut berasal dari impor sehingga harga pupuk menjadi mahal. Oleh karena itu perlu dicari alternatif untuk mengatasinya, yaitu dengan menggunakan batuan fosfat yang dicampur limbah cair tahu dan asam sulfat. Pupuk tersebut dinamakan Fosfatsuper, yang merupakan hasil asidulasi batuan fosfat dengan kombinasi antara 85\% limbah cair tahu dan $15 \% \mathrm{H}_{2} \mathrm{SO}_{4} 1 \mathrm{~N}$ Pupuk Fosfatsuper akan diuji kelarutannya dalam menyediakan unsur hara bagi tanaman jagung. Penelitian ini bertujuan mencari dosis dan ukuran butir pupuk Fosfatsuper yang terbaik dalam pertumbuhan dan serapan P tanaman jagung. Penelitian dilaksanakan di Rumah Kaca Ilmu Tanah, Laboratorium Ilmu Tanah dan Laboratorium Teknologi Pertanian Universitas Lampung bulan Agustus 2014 sampai April 2015. Penelitian disusun secara faktorial 2x4 dalam Rancangan Acak Kelompok (RAK) dengan 3 kelompok. Faktor pertama adalah dosis pupuk Fosfatsuper $\left(360 \mathrm{~kg} \mathrm{ha}^{-1} ; 720 \mathrm{~kg} \mathrm{ha}^{-1}\right)$ dan faktor kedua adalah ukuran butiran pupuk fosfat super ( $1 \mathrm{~mm}, 23 \mathrm{~mm}, 35 \mathrm{~mm},>5 \mathrm{~mm}$ ). Hasil penelitian menunjukkan bahwa P-tersedia terbaik pada dosis 50\% (setara dengan dosis SP-36 $360 \mathrm{~kg} \mathrm{ha}^{-1}$ ) pada ukuran butir $1 \mathrm{~mm}$ dan jumlah daun terbaik pada dosis 50\% pada ukuran butir $1 \mathrm{~mm}$. Berdasarkan hasil uji korelasi menunjukkan korelasi nyata antara serapan P dengan bobot berangkasan kering, P-tersedia dengan bobot berangkasan kering, dan $\mathrm{pH}$ dengan bobot akar kering tanaman jagung.
\end{abstract}

Kata kunci: asam sulfat, dosis pupuk, fosfatsuper, jagung, ukuran butir.

\section{PENDAHULUAN}

Unsur fosfor $(\mathrm{P})$ merupakan unsur hara yang sangat penting bagi pertumbuhan tanaman, baik untuk pertumbuhan vegetatif maupun generatif. Sumber $P$ yang saat ini digunakan dalam pertanian umumnya adalah pupuk kimia seperti SP-36 dan TSP. Dengan ditiadakannya subsidi pupuk $\mathrm{P}$ ini maka harga pupuk meningkat di pasaran karena semua bahan baku pembuatan pupuk tersebut berasal dari impor (Pramono, 2000). Oleh karena itu perlu dicari alternatif lain untuk mengatasinya, yaitu dengan menggunakan pupuk Fosfatsuper.

Pupuk alternatif Fosfatsuper merupakan hasil asidulasi batuan fosfat, 85\% limbar cair tahu, dan $15 \%$ $\mathrm{H}_{2} \mathrm{SO}_{4} 1 N$ (Aini, 2013). Berdasarkan penelitian Niswati dkk., (2014) limbah cair agroindustri yang berpotensi tinggi sebagai pelarut fosfat adalah limbah cair tahu. Hasil penelitian Aini (2013) menunjukkan kelarutan Ptotal batuan fosfat yang diasidulasi dengan $85 \%$ limbah cair tahu dan $15 \% \mathrm{H}_{2} \mathrm{SO}_{4} 1 \mathrm{~N}$ adalah $10,80 \%$. Fosfatsuper akan diujikan terhadap tanaman, indikator tanaman yang digunakan adalah tanaman jagung. Hal ini karena jagung merupakan tanaman yang sangat responsif terhadap pemupukan $P$.

Penelitian ini bertujuan untuk mencari dosis pupuk Fosfatsuper terbaik terhadap serapan $\mathrm{P}$ dan pertumbuhan tanaman jagung, mencari ukuran butir pupuk Fosfatsuper terbaik terhadap serapan $\mathrm{P}$ dan pertumbuhan tanaman jagung, dan mencari interaksi antara dosis dan ukuran butir pupuk Fosfatsuper terbaik terhadap serapan $\mathrm{P}$ dan pertumbuhan tanaman jagung.

\section{BAHAN DAN METODE}

Penelitian ini disusun secara faktorial $2 \times 4$ dalam Rancangan Acak Kelompok (RAK) dengan 3 kelompok. Faktor pertama adalah dosis pupuk Fosfatsuper $(\mathrm{P})$ yaitu $\mathrm{P}_{1}=360 \mathrm{~kg} \mathrm{ha}^{-1}$ atau setara dengan pupuk SP-36 dosis $100 \mathrm{~kg} \mathrm{ha}^{-1} ; \mathrm{P}_{2}=720 \mathrm{~kg} \mathrm{ha}^{-1}$ atau setara dengan pupuk SP-36 dosis $200 \mathrm{~kg} \mathrm{ha}^{-1}$. Faktor kedua adalah ukuran butir pupuk Fosfatsuper ( $\mathrm{T}$ ) yaitu $\mathrm{T}_{1}=1 \mathrm{~mm} ; \mathrm{T}_{2}=2-3$ $\mathrm{mm} ; \mathrm{T}_{3}=3-5 \mathrm{~mm} ;$ dan $\mathrm{T}_{4}=>5 \mathrm{~mm}$. Sehingga kombinasi perlakuan dari penelitian ini adalah $: \mathrm{P}_{1} \mathrm{~T}_{1}=$ 
$360 \mathrm{~kg} \mathrm{ha}^{-1}$ pupuk Fosfatsuper dengan ukuran butiran 1 $\mathrm{mm}, \mathrm{P}_{1} \mathrm{~T}_{2}=360 \mathrm{~kg} \mathrm{ha}^{-1}$ pupuk Fosfatsuper dengan ukuran butiran 2-3 mm, $\mathrm{P}_{1} \mathrm{~T}_{3}=360 \mathrm{~kg} \mathrm{ha}^{-1}$ pupuk Fosfatsuper dengan ukuran butiran 3-5 mm, $\mathrm{P}_{1} \mathrm{~T}_{4}=360 \mathrm{~kg} \mathrm{ha}^{-1}$ pupuk Fosfatsuper dengan ukuran butiran $>5 \mathrm{~mm}, \mathrm{P}_{2} \mathrm{~T}_{1}=720$ $\mathrm{kg} \mathrm{ha}^{-1}$ pupuk Fosfatsuper dengan ukuran butiran $1 \mathrm{~mm}$, $\mathrm{P}_{2} \mathrm{~T}_{2}=720 \mathrm{~kg} \mathrm{ha}^{-1}$ pupuk Fosfatsuper dengan ukuran butiran 2-3 mm, $\mathrm{P}_{2} \mathrm{~T}_{3}=720 \mathrm{~kg} \mathrm{ha}^{-1}$ pupuk Fosfatsuper dengan ukuran butiran 3-5 mm, dan $\mathrm{P}_{2} \mathrm{~T}_{4}=720 \mathrm{~kg} \mathrm{ha}^{-1}$ pupuk Fosfatsuper dengan ukuran butiran $>5 \mathrm{~mm}$. Homogenitas ragam antar perlakuan diuji dengan uji Bartlett dan aditivitas data diuji dengan uji Tukey. Jika asumsi terpenuhi, data dianalisis ragam dan dilanjutkan dengan uji BNT taraf 5\%. Uji korelasi dilakukan antara variabel utama dengan variabel pendukung.

Pada pembuatan pupuk fosfat super dan pemupukan, limbah cair tahu disiapkan dalam keadaan segar dan pelarut asam sulfat $\left(\mathrm{H}_{2} \mathrm{SO}_{4} 1 N\right)$. Tepung fosfat (lolos saringan $1 \mathrm{~mm}$ ) ditimbang $0,5 \mathrm{~kg}$. Kemudian sebanyak $0,5 \mathrm{~kg}$ tepung batuan fosfat, $425 \mathrm{ml}$ limbah cair tahu, dan $75 \mathrm{ml}\left(\mathrm{H}_{2} \mathrm{SO}_{4} 1 \mathrm{~N}\right)$ secara bersamaan dan perlahan-lahan dimasukkan ke dalam mixer selama 5 menit. Setelah itu campuran tersebut dituang ke dalam toples dan di diamkan selama seminggu, kemudian Fosfatsuper dibuat granul menggunakan alat granulator yang ada di Laboratorium Teknologi Pertanian Universitas Lampung. Setelah operasi granulasi selesai, hasilnya diambil dan dikeringkan dengan cara penjemuran langsung oleh sinar matahari. Pupuk yang sudah kering dianalisis distribusi diameter granul dengan menggunakan ayakan ( $1 \mathrm{~mm}, 2-3 \mathrm{~mm}, 3-5 \mathrm{~mm}$, dan >5 $\mathrm{mm})$.

Pada persiapan media tanam dan pemupukan, sebelum digunakan, tanah terlebih dahulu diayak dan dikeringkan. Selanjutnya $5 \mathrm{~kg}$ tanah dimasukkan ke dalam polibag, sebanyak 24 polibag sebagai perlakuan dan 3 polibag sebagai kontrol. Pemberian pupuk dasar dilakukan 1 MST dengan aplikasi urea dengan dosis 3 gram polibag $^{-1}$, dan aplikasi $\mathrm{KCl}$ dengan dosis 3 gram polibag $^{-1}$. Selain itu diberikan pupuk Fosfat Super dengan ukuran butiran $1 \mathrm{~mm}, 2-3 \mathrm{~mm}, 3-5 \mathrm{~mm}$, dan > $5 \mathrm{~mm}$ sehari setelah pemberian pupuk dasar dengan dosis rekomendasi $10,8 \mathrm{~g}$ polibag ${ }^{1}$ atau setara dengan $720 \mathrm{~kg}$ $\mathrm{ha}^{-1}$ dan $5,4 \mathrm{~g}$ polibag ${ }^{-1}$ atau setara dengan $360 \mathrm{~kg} \mathrm{ha}^{-1}$ sesuai perlakuan.

\section{HASIL DAN PEMBAHASAN}

Pada serapan $\mathrm{P}$ tanaman, dosis dan ukuran butiran tidak berpengaruh nyata terhadap serapan $\mathrm{P}$ tanaman jagung. Sedangkan dosis dan ukuran butiran pupuk Fosfatsuper terhadap serapan P pada tanaman jagung disajikan pada Gambar 1. Berdasarkan Gambar 1 dapat dilihat bahwa, terjadi peningkatan serapan $P$ yang cukup signifikan pada tanaman jagung setelah diberi perlakuan dosis dan ukuran butir Fosfatsuper jika dibandingkan dengan kontrol atau yang tidak diberi perlakuan dosis dan ukuran butir Fosfatsuper. Hal ini diduga karena menurut (Idawati, 1996) bahwa efisiensi pemupukan $P$ pada umumnya sangat rendah, yaitu kurang dari $10 \%$. Hal tersebut disebabkan oleh fiksasi $\mathrm{P}$ dalam tanah sehingga unsur $\mathrm{P}$ yang diberikan tidak seluruhnya tersedia bagi tanaman. Tingginya fiksasi $\mathrm{P}$ dalam tanah menyebabkan penimbunan $\mathrm{P}$ dalam tanah dari waktu ke waktu selama pemberian pupuk P dilakukan. Selain itu Sanchez (1992) menyatakan bahwa sebagian besar pupuk $\mathrm{P}$ yang tidak terserap oleh tanaman tidak hilang tercuci, tetapi menjadi non labil $\mathrm{P}$ yang tidak tersedia bagi tanaman.

Berdasarkan hasil analisis ragam menunjukkan bahwa dosis dan ukuran butiran pupuk Fosfatsuper tidak berpengaruh nyata terhadap P-tersedia tanah pada tanaman jagung. Namun terdapat interaksi yang nyata antara dosis dan ukuran butiran pupuk Fosfatsuper terhadap P-tersedia tanah pada tanaman jagung. Pengaruh interaksi antara dosis dan ukuran butiran pupuk fosfat super terhadap P-tersedia tanah pada tanaman jagung disajikan pada Tabel 1. Hal ini disebabkan karena fosfat alam yang digunakan secara langsung reaktivitasnya dipengaruhi oleh ukuran butir. Semakin halus ukuran butir fosfat alam maka semakin reaktif, karena semakin tinggi permukaan fosfat alam yang bersentuhan dengan permukaan koloid tanah. Selain

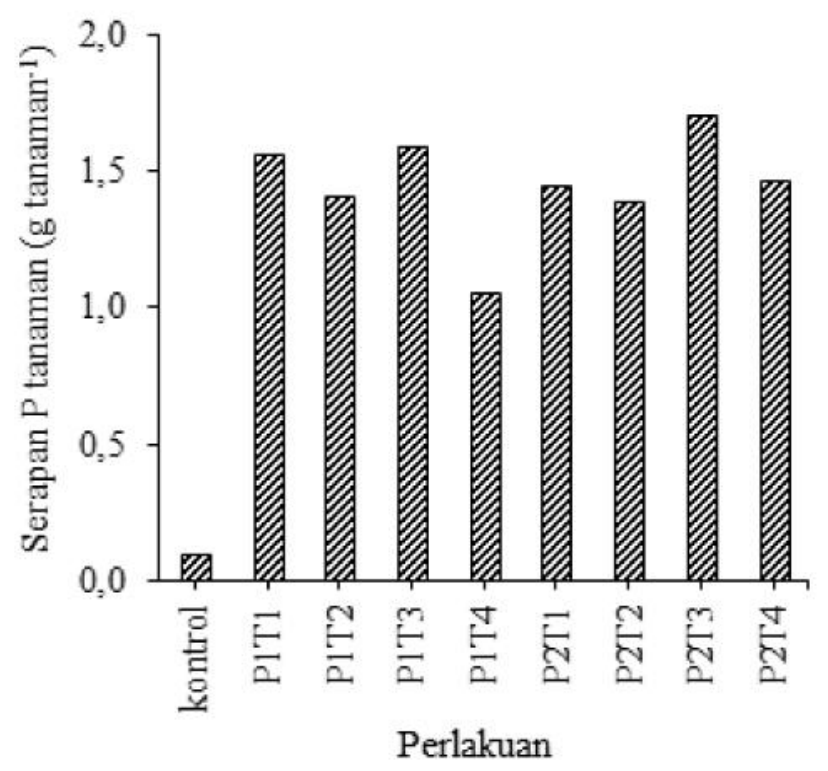

Gambar 1. Pengaruh perlakuan dosis dan ukuran butiran pupuk Fosfatsuper terhadap serapan P pada tanaman jagung. 
Tabel 1. Pengaruh interaksi antara dosis dan ukuran butiran pupuk Fosfatsuper terhadap P-tersedia tanah dan jumlah daun tanaman jagung.

\begin{tabular}{ccccc}
\hline \multirow{2}{*}{ Perlakuan } & \multicolumn{2}{c}{ P tersedia $(\mathrm{ppm})$} & \multicolumn{2}{c}{ Jumlah daun (helai) } \\
\cline { 2 - 5 } & $\mathrm{P}_{1}$ & $\mathrm{P}_{2}$ & $\mathrm{P}_{1}$ & $\mathrm{P}_{2}$ \\
\hline $\mathrm{T}_{1}$ & $13,80 \mathrm{a}$ & $8,05 \mathrm{a}$ & $43 \mathrm{a}$ & $41 \mathrm{a}$ \\
& $(\mathrm{A})$ & $(\mathrm{B})$ & $(\mathrm{A})$ & $(\mathrm{B})$ \\
$\mathrm{T}_{2}$ & $9,20 \mathrm{~b}$ & $7,83 \mathrm{a}$ & $38,5 \mathrm{c}$ & $40 \mathrm{~b}$ \\
& $(\mathrm{~A})$ & $(\mathrm{B})$ & $(\mathrm{B})$ & $(\mathrm{A})$ \\
$\mathrm{T}_{3}$ & $7,83 \mathrm{c}$ & $7,16 \mathrm{~b}$ & $39 \mathrm{c}$ & $42 \mathrm{c}$ \\
& $(\mathrm{A})$ & $(\mathrm{B})$ & $(\mathrm{B})$ & $(\mathrm{A})$ \\
$\mathrm{T}_{4}$ & $6,21 \mathrm{~d}$ & $6,14 \mathrm{c}$ & $42 \mathrm{~b}$ & $35 \mathrm{~d}$ \\
& $(\mathrm{~A})$ & $(\mathrm{A})$ & $(\mathrm{A})$ & $(\mathrm{B})$ \\
\hline BNT $5 \%$ & 0,66 & & 0,74 & \\
\hline
\end{tabular}

Keterangan: Nilai tengah yang diikuti oleh huruf yang sama tidak berbeda nyata pada taraf uji BNT 5\%. Huruf kecil dibaca arah vertikal dan huruf besar (dalam tanda kurung) dibaca arah horizontal. $\mathrm{P}_{1}=360 \mathrm{~kg} \mathrm{ha}^{-1}$ Fosfatsuper; $\mathrm{P}_{2}=720 \mathrm{~kg} \mathrm{ha}^{-1}$ Fosfatsuper; $\mathrm{T}_{1}=$ ukuran butiran $1 \mathrm{~mm} ; \mathrm{T}_{2}=$ ukuran butiran 2-3 mm; $\mathrm{T}_{3}=$ ukuran butiran $3-5 \mathrm{~mm} ; \mathrm{T}_{4}=$ ukuran butiran $>5 \mathrm{~mm}$.

itu hal ini diduga karena meningkatnya $100 \%$ dosis rekomendasi, menyebabkan semakin banyak P yang teretensi sehingga $P$ tidak tersedia bagi tanaman. Selain itu, diketahui bahwa P-tersedia pada tanah dipengaruhi oleh $\mathrm{pH}$ tanah. Unsur hara P paling mudah diserap oleh tanaman pada pH sekitar 6-7 (Hardjowigeno, 1987). Pada $\mathrm{pH}>5,0$ unsur hara fosfat kurang tersedia pada tanah masam. Ketersediaan P di dalam tanah berbanding lurus dengan $\mathrm{pH}$ tanah. Bila tanah masam ketersediaan $\mathrm{P}$ akan menurun, sebaliknya jika $\mathrm{pH}$ tanah meningkat sampai $\mathrm{pH}$ tertentu, maka ketersediaan $\mathrm{P}$ juga akan meningkat.

Pengaruh interaksi antara dosis dan ukuran butiran pupuk Fosfatsuper terhadap jumlah daun tanaman jagung disajikan pada Tabel 1. Berdasarkan hasil analisis ragam ukuran butiran berpengaruh nyata terhadap jumlah daun pada tanaman jagung, sedangkan dosis pupuk Fosfatsuper tidak berpengaruh nyata terhadap jumlah daun pada tanaman jagung. Namun interaksi antara dosis dan ukuran butiran pupuk Fosfatsuper berpengaruh nyata terhadap jumlah daun pada tanaman jagung. Terjadinya interaksi yang nyata antara dosis dan ukuran butiran terhadap jumlah daun tanaman jagung menunjukkan bahwa tanaman jagung sangat responsif terhadap pemupukan P. Di samping itu fosfor berperan sebagai bahan penyusun nukleoprotein (inti sel) yang menentukan proses pembelahan inti sel (Hakim, 1982). Dengan demikian kekurangan $\mathrm{P}$ dapat menghambat proses pembelahan inti sel sehingga pertumbuhan akan terhambat. Selain itu juga peningkatan jumlah daun karena unsur fosfor berperan dalam proses pembentukan energi pada tanaman sehingga dengan peningkatan pemberian P maka akan meningkatkan laju fotosintesis, sejalan dengan itu dapat merangsang pembentukan daun baru yang meningkat.

Berdasarkan hasil analisis ragam dosis dan ukuran butiran pupuk Fosfatsuper tidak berpengaruh nyata terhadap tinggi tanaman jagung pada 9 MST. Pengaruh dosis dan ukuran butiran terhadap tinggi tanaman jagung disajikan pada Gambar 2. Pada gambar 2 dapat dilihat peningkatan tinggi tanaman pada setiap minggu pengamatan adalah sama antar semua perlakuan dan kurva peningkatan tinggi tanaman sesuai dengan kurva tinggi tanaman pada umumnya, yaitu sigmoid, dengan kecepatan peningkatan tertinggi diperoleh pada tanaman jagung umur 4-7 MST, kemudian melambat. Hal ini sejalan dengan hasil penelitian Komariah (2007) yang menunjukkan perlakuan pupuk fosfor tidak berpengaruh nyata terhadap tinggi tanaman jagung semi. Danarti (1992) pertumbuhan tinggi tanaman jagung tidak terlepas dari sifat fisika tanah yang mampu menciptakan kondisi yang baik bagi pertumbuhan akar. Dengan sifat fisika tanah yang lebih baik maka ketersedian air, unsur hara yang ada akan lebih mudah diserap oleh akar tanaman dan mampu menstimulir tinggi tanaman.

Dosis dan ukuran butiran tidak berpengaruh nyata terhadap bobot berangkasan kering pada tanaman jagung. Pengaruh dosis dan ukuran butiran pupuk Fosfatsuper terhadap bobot berangkasan kering disajikan pada Gambar 3. Berdasarkan Gambar 3 dapat dilihat bahwa, pada perlakuan bobot berangkasan kering tanaman lebih rendah berkisar antara 23,16 $\mathrm{g}_{\text {tanaman }}{ }^{-1}$ dibanding 
perlakuan lainnya. Sedangkan pada semua perlakuan berkisar antara $\left(23,16-37,52 \mathrm{~g} \operatorname{tanaman}^{-1}\right)$. Sugito (1994) dengan semakin meningkatnya sumber karbohidrat yang dihasilkan daun akan semakin besar jumlah asimilat. Akibatnya terbentuk sistem perakaran yang lebih luas

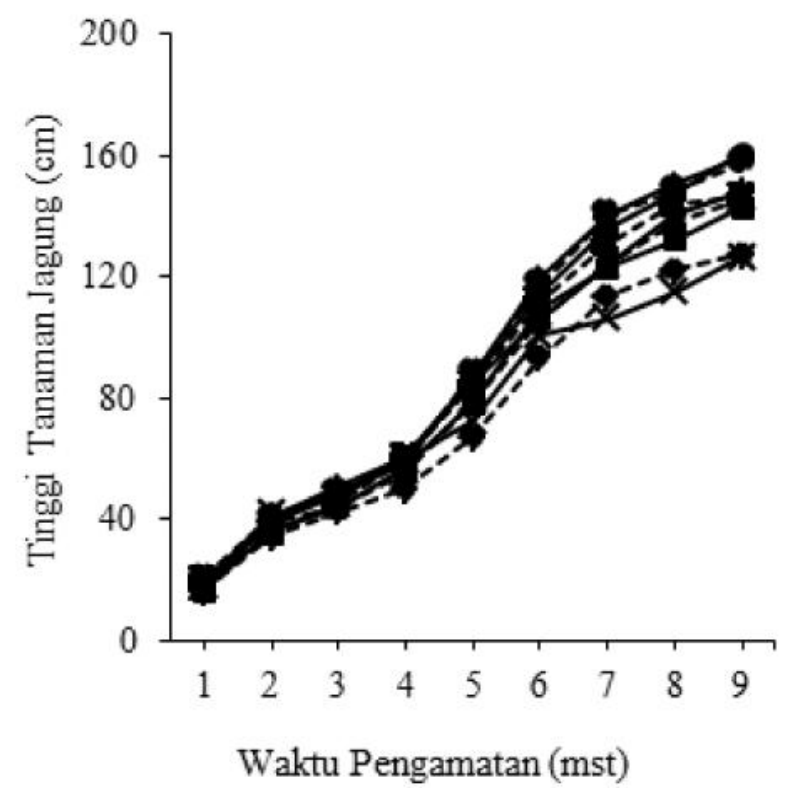

Gambar 2. Pengaruh pemberian dosis dan ukuran butiran pupuk Fosfatsuper terhadap tinggi tanaman jagung. $\rightarrow$ * $=$ kontrol, $\rightarrow-\mathrm{C}=\mathrm{P} 2 \mathrm{~T} 4, \boldsymbol{-}$ $=\mathrm{P} 2 \mathrm{~T} 3, \multimap=\mathrm{P} 2 \mathrm{~T} 2, \boldsymbol{\bullet}=\mathrm{P} 2 \mathrm{~T} 1, \boldsymbol{-}-\mathbf{- =}$ $\mathrm{P} 1 \mathrm{~T} 4, \cdot \boldsymbol{-} \boldsymbol{k}-\mathrm{P} 1 \mathrm{~T} 3, \boldsymbol{\bullet} \bullet-\mathbf{- P} 1 \mathrm{~T} 2, \cdot \bullet-\boldsymbol{-}=$ P1T1.

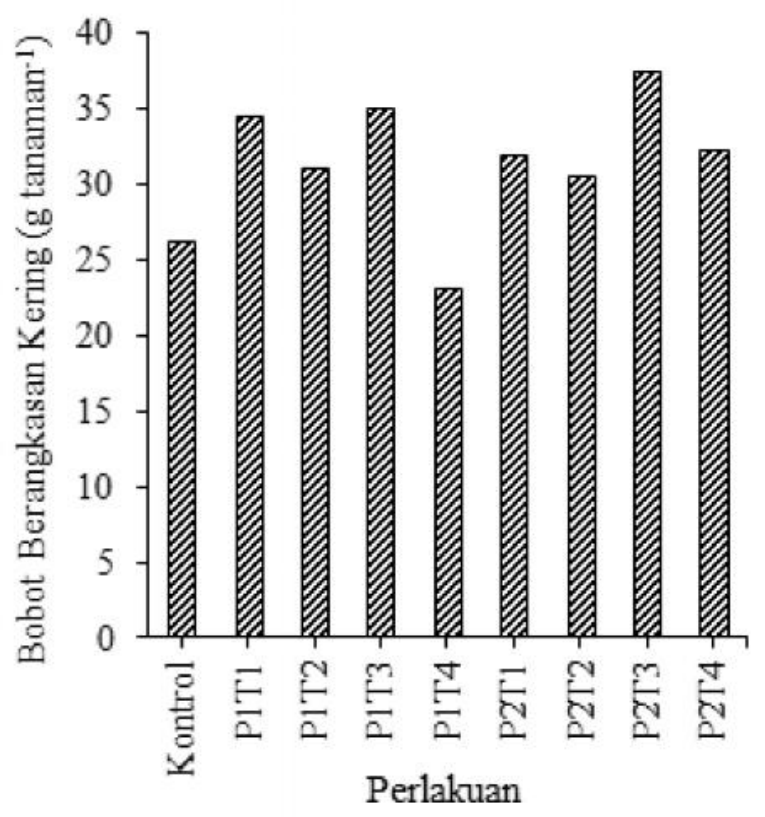

Gambar 3. Pengaruh perlakuan dosis dan ukuran butiran pupuk Fosfatsuper terhadap bobot berangkasan kering pada tanaman jagung. dan struktur vegetatif yang lebih besar saat terjadi pembentukan biji dan buah. Dengan begitu pertumbuhan tajuk biasanya sebanding dengan pertumbuhan akar. Namun pada penelitian ini penambahan pupuk Fosfatsuper tidak berpengaruh pada bobot basah maupun bobot kering tajuk dan akar. Hal ini berarti pencapaian konsentrasi fosfat pada tajuk belum mampu menghasilkan fotosintat baru yang lebih efisien dan memindahkan lebih banyak fotosintat ke akar untuk mempertahankan laju penyerapan hara.

Dosis dan ukuran butiran pupuk Fosfatsuper tidak berpengaruh nyata terhadap $\mathrm{pH}$ tanah pada tanaman jagung. Pengaruh dosis dan ukuran butiran pupuk fosfat super disajikan pada Gambar 4. Pada gambar 4 dapat dilihat bahwa, $\mathrm{pH}$ tanah berkisar antara $(5,74-6,50)$. Data $\mathrm{pH}$ ini menunjukkan bahwa $\mathrm{pH}$ tergolong kriteria pH agak masam. Hal ini terjadi diduga karena tanaman dapat mempengaruhi $\mathrm{pH}$, perubahan $\mathrm{pH}$ pada rizosfer mengakibatkan ketidakseimbangan anion dan kation.

Berdasarkan hasil uji korelasi (Tabel 3) menunjukkan korelasi yang nyata antara Serapan P dan P-tersedia dengan bobot berangkasan kering. Peningkatan bobot berangkasan kering tanaman menurut Rao (1994), P berperan dalam transfer energi. Senyawa $\mathrm{P}$ untuk transfer energi terdapat dalam bentuk ADP (Adenosin Difosfat), ATP (Adenosin Trifosfat) dan fosfor organik. Apabila unsur P dalam keadaan kurang maka akan mengganggu metabolisme tanaman. Dengan terganggunya metabolisme tanaman maka pertumbuhan tanaman akan terganggu pula. Selain itu

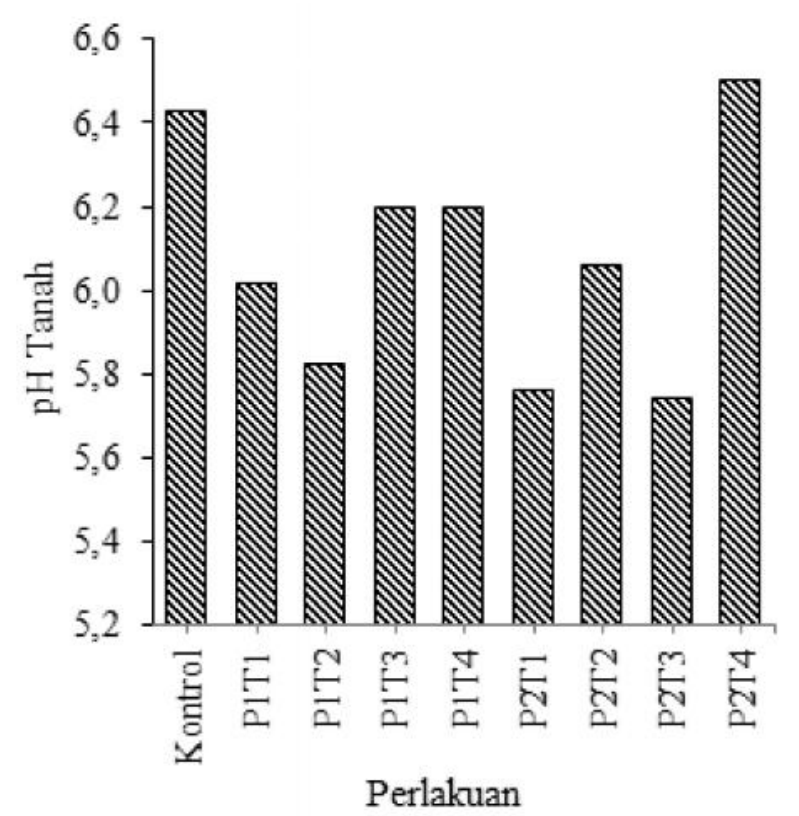

Gambar 4. Perubahan $\mathrm{pH}$ tanah dengan menggunakan perlakuan dosis dan ukuran butiran pupuk Fosfatsuper pada tanaman jagung. 
Tabel 3. Hasil korelasi antara serapan P tanaman, P-tersedia, dan pH dengan Tinggi Tanaman, Jumlah Daun, Bobot Berangkasan Kering Tanaman, Bobot Akar Kering.

\begin{tabular}{ccccc}
\hline \multirow{2}{*}{ Variabel } & \multicolumn{4}{c}{ Koefisisen korelasi (r) } \\
\cline { 2 - 5 } & Tinggi tanaman & Jumlah daun & Bobot akar kering & Bobot tajuk kering \\
\hline Serapan P & $0,20^{\text {tn }}$ & $0,24^{\text {tn }}$ & $0,41^{*}$ & $0,20^{\text {tn }}$ \\
P-tersedia & $-0,16^{\text {tn }}$ & $-0,16^{\text {tn }}$ & $0,42^{*}$ & $0,13^{\text {tn }}$ \\
pH & $0,10^{\text {tn }}$ & $-0,12^{\text {tn }}$ & $0,12^{\text {tn }}$ & $0,52^{*}$ \\
\hline
\end{tabular}

Keterangan: $*$ berkorelasi nyata pada taraf $5 \% \mathrm{tn}=$ tidak berkorelasi nyata padataraf $5 \%$

terjadi korelasi positif antara $\mathrm{pH}$ tanah dengan bobot kering akar tanaman. Hal ini disebabkan karena sumbangan $\mathrm{P}$ dari fosfat alam ke dalam tanah diserap akar tanaman digunakan dalam penyusunan organ tanaman. Sehingga mempengaruhi pertumbuhan dan produksi $\mathrm{P}$ dalam tanah meningkat sehingga merangsang pertumbuhan perakaran tanaman.

\section{KESIMPULAN}

Berdasarkan penelitian ini maka dapat disimpulkan bahwa idak terdapat dosis pupuk fosfatsuper yang terbaik dalam mempengaruhi serapan $\mathrm{P}$ dan pertumbuhan tanaman jagung. Tidak terdapat ukuran butir pupuk fosfatsuper yang terbaik dalam mempengaruhi serapan $\mathrm{P}$ dan pertumbuhan tanaman jagung. Terdapat interaksi antara dosis dan ukuran butir pupuk Fosfatsuper terhadap P-tersedia dan jumlah daun. P-tersedia terbaik pada dosis $50 \%$ pada ukuran butir 1 $\mathrm{mm}$. Sedangkan Jumlah daun terbaik pada dosis $50 \%$ pada ukuran butir $1 \mathrm{~mm}$.

\section{DAFTAR PUSTAKA}

Aini, S. N. 2013. Pengaruh Perbandingan Campuran Limbah Cair Tahu dengan Asam Sulfat serta Lama Inkubasi dalam Proses Asidulasi Batuan Fosfat terhadap Fosfat Larut. Skripsi. Universitas Lampung. Bandarlampung. $54 \mathrm{hlm}$.
Danarti, S. dan Najiati. 1996. Bercocok Tanam Jagung Manis. Penebar Swadaya. Jakarta. 67 hlm.

Hardjowigeno, S. 1987. Ilmu Tanah. PT. Mediyatama Sarana Perkasa, Jakarta. 286 hlm.

Hakim, N., M. Y. Nyakpa, A. M. Lubis, S. G. Nugroho, M. R Saul, M. A. Diha, G. B. B. Hong, dan H. H. Bailey. 1986. Dasar-dasar Ilmu Tanah. Universitas Lampung. Lampung. $488 \mathrm{hlm}$.

Idawati A., Haryanto, dan H. Rasjid. 1996. Serapan hara dan Pertumbuhan Padi Sawah Sehubungan dengan status Unsur Hara $P$ pada Tanah Pustaka Negara. Pusat Aplikasi Isotop dan Radiasi. Batan. 103108 hlm.

Niswati A., S. Yusnaini, dan Sarno. 2014. The potency of agroindustrial wastewaters for increasing soluble-P from phosphate rock . J. Trop. Soils $19(1): 2$.

Raihana, Y. 1992. Pengaruh pemberian kapur dan fosfat alam pada tanaman jagung di lahan pasang surut sulfat masam. Risalah Seminar Hasil Penelitian Tanaman Pangan. Peneliti Agronomi Balittan Banjarbaru. 183-189 hlm.

Rao, S.N.S. 1994. Mikroorganisme Tanah dan Pertumbuhan Tanaman. Universitas Indonesia Press. Jakarta.

Shancez, P. A. 1992. Sifat dan Pengolahan Tanah Tropika. Terjemahan: Jayadinata, Jilid I. ITB. Bandung. $162-181$. 